\title{
Cytological picture of the oral mucosa in patients with gastric and colon cancer
}

\author{
Bożena Kędra ${ }^{1}$, Monika Chomczyk ${ }^{2,3}$, Marcin Złotkowski ${ }^{1}$, Wanda Stokowska ${ }^{4}$, \\ Agnieszka Borsuk ${ }^{5}$, Mieczysław Bicz ${ }^{5}$, Małgorzata Pietruska ${ }^{1}$, Grażyna Tokajuk ${ }^{1}$, \\ Radosław Charkiewicz ${ }^{3}$, Piotr Czajka ${ }^{5}$, Lech Chyczewski ${ }^{5}$, Lech Zimnoch ${ }^{5}$, Bogusław Kędra ${ }^{2}$ \\ ${ }^{1}$ Department of Periodontal and Oral Mucosa Diseases, Medical University of Bialystok, Poland \\ ${ }^{2}$ II General and Gastroenterological Surgery Clinic, Medical University of Bialystok, Poland \\ ${ }^{3}$ Department of Clinical Molecular Biology, Medical University of Bialystok, Poland \\ ${ }^{4}$ Department of Preservative Dentistry, Medical University of Bialystok, Poland \\ ${ }^{5}$ Department of Clinical Pathomorphology, Medical University of Bialystok, Poland
}

\begin{abstract}
The incidence of malignant gastrointestinal cancers in Poland has been constantly growing, which has led to an intensification of the search for new markers of the early clinical stage of this disease. The oral cavity, as the first part of the gastrointestinal tract, has a very important role. The oral cavity presents symptoms of both typically stomatological and systemic diseases. Oral cancers, benign or malignant, may originate and grow in any of the tissues of the mouth, and within this small area they may be of varied clinical, histological and biological features. These can be lesions typically observed in the oral cavity, but also characteristic of cases where the symptoms occur both in the mouth and in other body parts. The aim of this study was to present a cytological picture of the oral mucosa in patients with gastric and colon cancer and to compare the cytological picture with that obtained from a group of patients with no cancer, using the Papanicolaou classification and the Bethesda system. The study was conducted in 126 patients treated surgically in the II General and Gastroenterological Surgery Clinic between 2006 and 2008. All patients were divided into two groups based on the type of lesions. In both of the studied groups, more than half of the patients did not present any abnormalities in the mucosa of the mouth, lips and cheeks in the physical examination. None of the patients had erosion, ulceration or lesions typical of leukoplakia or lichen planus. No malignant cells were detected in either of the studied groups, and there were no well-defined lesions found in the oral cavity that would distinguish the patients with gastrointestinal cancer. (Folia Histochemica et Cytobiologica 2012, Vol. 50, No. 3, 375-380)
\end{abstract}

Key words: oral mucosa, cytological picture, gastric cancer, colon cancer

\section{Introduction}

The incidence of malignant gastrointestinal cancers in Poland has been constantly growing, especially the colon and the pancreas. This has resulted in an inten-

Correspondence address: M. Chomczyk,

II General and Gastroenterological Surgery Clinic,

Department of Clinical Molecular Biology,

Medical University of Bialystok,

Waszyngtona Str. 13, 15-269 Bialystok, Poland;

tel.: + 48857485935 , fax: + 48857485988 ;

e-mail: m.chomczyk@wp.pl sification of the search for new markers of the early clinical stage of this disease. The oral cavity, as the first part of the gastrointestinal tract, plays a very important role. It receives food and allows for the intake of elements necessary for bodily functions. Obviously, other roles of the oral cavity are equally important, but these have already been described in numerous handbooks of human physiology. Unfortunately, as with every other organ, the oral cavity is constantly subjected to various disease processes. Most of the diseases are caused by local factors and can be easily diagnosed. In addition to the local factors, also systemic diseases and especially diseases and 
infections of the blood, the digestive tract and the skin, can give symptoms in the oral cavity [1,2]. Except for the obvious, e.g. cancer, pemphigus, few diseases of the oral cavity are life threatening. Despite all this knowledge, early detection and following up with early treatment, especially of cancer, is still unsatisfactory, even though the oral cavity is easily accessible for clinical examination and diagnosis to every doctor, and particularly to dentists [3-7].

The possibility of conducting microbiological, biochemical or molecular tests gives hope for an early detection, especially of neoplastic and systemic diseases [8-10]. The available literature offers many reports on diseases of the oral mucosa in the course of systemic diseases and also of cancer. However, they mainly present a description of the local lesions in the course of a particular illness, whereas there is not much data on the evaluation of the state of the oral mucosa in patients with gastrointestinal tract cancer.

The oral cavity presents symptoms of both typically stomatological and systemic diseases. Oral cancers, benign or malignant, may originate and grow in any of the tissues of the mouth, and within this small area they may be of varied clinical, histological and biological features [11]. These can be lesions typically observed in the oral cavity, but also characteristic of cases where the symptoms occur both in the mouth and in other body parts [4].

The aim of this study was to present a cytological picture of the oral mucosa in patients with gastric and colon cancer. Additionally, we compare the cytological picture to that obtained from a group of patients with no cancer, using the Papanicolaou classification and the Bethesda system.

\section{Material and methods}

The study was conducted in 126 patients treated surgically in the II General and Gastroenterological Surgery Clinic of the Medical University of Bialystok between 2006 and 2008. All patients were divided into two groups based on the type of lesions. Group I consisted of patients with histopathologically confirmed gastrointestinal epithelial neoplasia. The group comprised 86 patients ( 35 females and 51 males, mean age 64.2 years, range $26.5-88$ ). There were 50 patients with colon cancer and 36 patients with gastric cancer. Group II, a control group, consisted of 40 patients ( 19 females and 21 males, mean age 54.42 years, range $22-81$ ) with benign, nonneoplastic lesions of gastrointestinal tract. They were hospitalized due to: abdominal hernia -14 , gallstones -5 , benign pancreatic lesions -5 , benign bowel lesions -13 , and nodular thyroid goiter -3 .

Most oral cavity cancers originate in the healthy mucosa, though some begin as clinically visible, potentially malignant lesions (erythroplakia, leukoplakia). One of the main pre-cancerous lesions is epithelial dysplasia - a term denoting a disturbance of cell maturation and proliferation. The dysplasia is divided into severity categories, with a high malignancy potential in the more severe, advanced, stages.

The studied groups of patients, after having their medical history taken, were thoroughly examined by a dentist (in accordance with a commonly accepted protocol). Next, a brush biopsy was performed from the inner lining of the right cheek using a sterile brush Cytobrush ${ }^{\circledR}$ Plus GT (Medscand Medical). In cases when pathological changes were noted in the right cheek, a smear was also collected from the inner lining of the left cheek. The obtained specimens were then placed on silanized glass slides and fixed with Fixocyt spray (POCH). In the laboratory, the Papanicolaoustained smears were assessed according to the five-grade Papanicolaou classification of malignancy [10]. Additionally, the specimen was assessed according to the Bethesda system.

\section{Results}

\section{Macroscopic picture of the oral cavity}

In both of the studied groups, more than half of the patients did not present any abnormalities in the mucosa of the mouth, lips and cheeks in the physical examination. None of the patients had erosion, ulceration or lesions typical of leukoplakia or lichen planus. A comparable incidence of macroscopic changes was observed in the group of noncancerous patients i.e. the control group. The predominant pathological lesion was a coated tongue; additionally, we observed the following symptoms: a smooth tongue, a red tongue, angular cheilitis and stomatitis prothetica. These lesions need to be considered as secondary, resulting from deficiencies caused by a primary disease and by the Candida infections. Pathological changes observed in the physical examination of the mouth are presented in Table 1.

\section{Cytological picture of the oral cavity}

Cytology is a relatively simple, non-invasive study that helps to detect early stage neoplastic lesions [6]. It gives clinicians a picture of a cell at a particular moment of its changes. Specific meaning of cytology is seen when atypical cells are revealed and their presence suggests the need for histopathological examination $[3,5,12]$.

Cytological picture of the oral cavity is shown in Table 2 (according to the Papanicolaou classification) and in Table 3 (according to the Bethesda system). In both of the studied groups, regardless of the system used for the diagnostic cytology, positive results were predominant (class I and II according to the Papani- 
Table 1. Features of dysplasia

\begin{tabular}{|c|c|}
\hline Disturbances of maturation & Disturbed proliferation \\
\hline Irregular hyperplasia and/or atrophy & Loss of polarity of basal cells \\
\hline Keratosis/parakeratosis & Basal cell hyperplasia \\
\hline Drop-shaped rete ridges & Increased nuclear-cytoplasmic ratio \\
\hline Irregular epithelial stratification & Enlarged nucleoli \\
\hline Disturbed cell proliferation & Hyperchromatism \\
\hline Cell keratinization & Increased number of mitoses \\
\hline Reduced intercellular cohesion & Anisonucleosis \\
\hline Cellular pleomorphism & Abnormal mitotic figures \\
\hline
\end{tabular}

Table 2. Grades of epithelial dysplasia and carcinoma in situ

\begin{tabular}{|l|l|}
\hline Mild dysplasia & Atypical and immature basal cells extend from the basal layer to the lower third of the epithelium \\
\hline Moderate dysplasia & Atypical and immature basal cells extend from the basal layer to the middle third of the epithelium \\
\hline Severe dysplasia & Atypical and immature basal cells invade through the full thickness of the epithelium \\
\hline Carcinoma in situ & Atypical and immature basal cells invade through the full thickness of the epithelium and the basal layer \\
\hline
\end{tabular}

Table 3. The Papanicolaou classification

\begin{tabular}{|l|l|}
\hline $\begin{array}{l}\text { Class I } \\
\text { Normal }\end{array}$ & Absence of abnormal or atypical cells \\
\hline $\begin{array}{l}\text { Class II } \\
\text { Normal/atypical }\end{array}$ & $\begin{array}{l}\text { Atypical cells, but no evidence } \\
\text { of malignancy }\end{array}$ \\
\hline $\begin{array}{l}\text { Class III } \\
\text { Suspicious }\end{array}$ & $\begin{array}{l}\text { Undefined - cytology suggestive of, } \\
\text { but not conclusive for, malignancy }\end{array}$ \\
\hline $\begin{array}{l}\text { Class IV } \\
\text { Suggestive }\end{array}$ & $\begin{array}{l}\text { Cytology strongly suggestive } \\
\text { of malignancy }\end{array}$ \\
\hline $\begin{array}{l}\text { Class V } \\
\text { Indicative }\end{array}$ & Cytology conclusive for malignancy \\
\hline
\end{tabular}

colaou test; normal smears and LSIL according to the Bethesda system). No malignant cells were detected in either of the studied groups. Additionally, there were no well-defined lesions found in the oral cavity that would distinguish those patients with gastrointestinal cancer.

\section{Discussion}

A macroscopic evaluation of the oral mucosa performed during the physical examination of the patients with gastrointestinal epithelial cancer, and patients from the control group, revealed similar results. No significant morphological changes were found that would distinguish those patients with cancer [13]. Regardless of the cancer location, the percentage of the detected pathological lesions was comparable between the groups of patients with gastric cancer and those with colon cancer. The detected pathological
Table 4. Cytology classification according to the Bethesda system

\begin{tabular}{|l|}
\hline Normal smear result \\
\hline ASC-US (atypical squamous cells of undetermined significance) \\
\hline LSIL (low-grade squamous intraepithelial lesions) \\
\hline HSIL (high-grade squamous intraepithelial lesions) \\
\hline Invasive carcinoma \\
\hline
\end{tabular}

lesions were found in matching locations and affected the dorsum of the tongue, the corners of the mouth and the hard palate. Their intensity depends on the patient's body defense system and the effectiveness of hygienic treatments in the hospital environment $[2,6,7]$.

A discussion of our own results is difficult because there is still not much data on the evaluation of the state of the oral mucosa in patients with gastrointestinal cancer. Fukushima et al. have presented patients with advanced gastric cancer who have diffuse changes in the angles of the lips, oral mucosa and esophagus of the type acanthosisnigricans [14].

Wijn et al. have pointed out that patients with familial adenomatous polyposis (FAP) include an increased risk of jaw osteomas, odontomas and supernumerary or unerupted teeth. Early diagnosis of FAP is crucial, and may be life saving. As oral signs usually precede gastrointestinal symptoms, the dentist may play an important role in the diagnosis of FAP [15].

The results of our study are comparable with those on oral cavity lesions in patients with cirrhosis [16] and ulcerative colitis [17] published by Knychalska- 
Table 5. Macroscopic changes in the oral mucosa

\begin{tabular}{|l|c|c|c|c|}
\hline & \multicolumn{2}{|c|}{ Group I } & \multicolumn{2}{c|}{ Control group } \\
\hline Pathological changes & \multicolumn{2}{|c|}{$\mathbf{n}=\mathbf{8 6}(\mathbf{1 0 0 \%}$} & \multicolumn{2}{c|}{$\mathbf{n}=\mathbf{4 0}(\mathbf{1 0 0 \% )}$} \\
\hline Stomatitis prothetica & 2 & $2.33 \%$ & 1 & $2.50 \%$ \\
\hline Coated tongue & 20 & $23.26 \%$ & 8 & $20.00 \%$ \\
\hline Red tongue & 5 & $5.81 \%$ & 0 & $0.00 \%$ \\
\hline Smooth tongue & 7 & $8.14 \%$ & 3 & $7.50 \%$ \\
\hline Fissured tongue & 0 & $0.00 \%$ & 3 & $7.50 \%$ \\
\hline Angular cheilitis & 3 & $3.49 \%$ & 0 & $0.00 \%$ \\
\hline Lichen planus, leukoplakia & 0 & $0.00 \%$ & 0 & $0.00 \%$ \\
\hline Dryness, burning & 3 & $3.49 \%$ & 1 & $2.50 \%$ \\
\hline Redness of the oral mucosa & 2 & $2.33 \%$ & 1 & $2.50 \%$ \\
\hline Thinning of the oral mucosa & 3 & $3.49 \%$ & 0 & $0.00 \%$ \\
\hline Erosion, ulceration & 0 & $0.00 \%$ & 0 & $0.00 \%$ \\
\hline All changes & 45 & $52.33 \%$ & 17 & $42.50 \%$ \\
\hline Patients with changes in the oral cavity & 32 & $37.21 \%$ & 14 & $35.00 \%$ \\
\hline Patients with no changes in the oral cavity & 54 & $62.79 \%$ & 26 & $65.00 \%$ \\
\hline
\end{tabular}

Table 6. Microscopic changes in the oral mucosa according to the Papanicolaou classification

\begin{tabular}{|l|c|c|c|c|}
\hline & \multicolumn{2}{|c|}{$\begin{array}{c}\text { Group I } \\
\text { Patients with cancer }\end{array}$} & \multicolumn{2}{c|}{ Control group } \\
\hline Cytological picture & \multicolumn{2}{|c|}{$\mathbf{n = 8 6}(\mathbf{1 0 0} \%)$} & \multicolumn{2}{c|}{$\mathbf{n}=\mathbf{4 0}(\mathbf{1 0 0 \%})$} \\
\hline Class I & 24 & $27.90 \%$ & 6 & $15.00 \%$ \\
\hline Class II & 42 & $48.84 \%$ & 26 & $65.00 \%$ \\
\hline Class III & 9 & $10.47 \%$ & 8 & $20.00 \%$ \\
\hline Class IV & 11 & $12.79 \%$ & 0 & $0.00 \%$ \\
\hline Class V & 0 & $0.00 \%$ & 0 & $0.00 \%$ \\
\hline Dyskeratotic cells & 29 & $33.72 \%$ & 1 & $2.50 \%$ \\
\hline Koilocytes & 13 & $15.12 \%$ & 2 & $5.00 \%$ \\
\hline Candida & 5 & $5.81 \%$ & 2 & $5.00 \%$ \\
\hline
\end{tabular}

Table 7. Cytological picture of the oral cavity according to the Bethesda system

\begin{tabular}{|l|c|c|c|c|}
\hline & \multicolumn{2}{|c|}{$\begin{array}{c}\text { Group I } \\
\text { Patients with cancer }\end{array}$} & \multicolumn{2}{c|}{$\mathbf{n}=\mathbf{4 0}(\mathbf{1 0 0 \%})$} \\
\hline Cytological picture & \multicolumn{2}{|c|}{$\mathbf{n = 8 6}(\mathbf{1 0 0 \%})$} & 71 & $77.50 \%$ \\
\hline Normal smear result & 68 & $9.30 \%$ & 7 & $17.50 \%$ \\
\hline ASCUS & 8 & $11.63 \%$ & 2 & $5.00 \%$ \\
\hline LSIL & 10 & $0.00 \%$ & 0 & $0.00 \%$ \\
\hline HSIL & 0 & $0.00 \%$ & 0 & $0.00 \%$ \\
\hline Invasive carcinoma & 0 & $33.72 \%$ & 1 & $2.50 \%$ \\
\hline Dyskeratotic cells & 29 & $15.12 \%$ & 2 & $5.00 \%$ \\
\hline Koilocytes & 13 & $5.81 \%$ & 2 & $5.00 \%$ \\
\hline Candida & 5 & & \\
\hline
\end{tabular}


Table 8. Comparison of the systems for diagnostic cytology

\begin{tabular}{|c|c|}
\hline The Bethesda system & $\begin{array}{c}\text { The Papanicolaou } \\
\text { classification }\end{array}$ \\
\hline Within normal limits & I \\
\hline $\begin{array}{c}\text { Infection } \\
\text { Reactive and reparative changes }\end{array}$ & II \\
\hline ASCUS & No equivalent \\
\hline LSIL & III \\
\hline HSIL & III \\
\hline HSIL & IV \\
\hline Squamous cell carcinoma & V \\
\hline
\end{tabular}

Karwan. Malins and Baumgart have obtained similar results in many other chronic diseases of the digestive tract, especially inflammatory bowel disease. Similarly, uncharacteristic changes observed in the oral cavity are more frequent, and their nature depends primarily on nutritional deficiency, iron deficiency, vitamin B12, folic acid, used drugs or malabsorption syndrome $[18,19]$.

Comparing cytological pictures of patients with gastrointestinal tract cancer and the control group, it is difficult to draw simple conclusions if using the Papanicolaou classification [20]. Significant differences are observed in the percentage distribution of the particular Papanicolaou classes. At the same time, the number of dyskeratotic cells and koilocytes is different in both of the studied groups. However, when using the Bethesda system for diagnostic cytology, the differences observed between the two studied groups are less distinct. Due to a small number of lesions found in the studied patients, statistical tests were not used to evaluate the analyzed parameters. Substantial differences were observed in the percentage distribution of the results, but it is difficult to state whether they are statistically significant. Additionally, evaluation of cytological specimens was performed on the basis of systems for diagnostic cytology primarily created for the analysis of cervical smears. Evaluation of lesions in the oral cavity according to the Papanicolaou classification has previously been attempted $[5,12,21]$. The National Cancer Institute in Bethesda (USA) proposed replacing the Papanicolaou classification with another method called the Bethesda system [22]. The Bethesda system for reporting cervical/vaginal diagnoses was introduced to replace the numerical Papanicolaou class designations, thereby facilitating precise communications between cytopathologist and clinician.

Although this system is intended for the evaluation of cervical specimens, we attempted to use it to assess the specimen from the oral cavity, since the oral stratified squamous epithelium and the cervical stratified squamous epithelium are similarly built.

It is possible that cancerous lesions, due to an accompanying inflammatory reaction, can change the cytological picture, which is reflected in the comparison of the studied groups of patients. The number of abnormal smear results (class III and IV) is noticeably higher in patients with gastrointestinal epithelial neoplasia assessed according to the Papanicolaou classification. On the contrary, in the cytological assessment performed using the Bethesda system, these differences were not observed. It is not currently possible to select a classification that is more useful in stomatology, and so further studies are necessary.

In conclusion, we have not found any macro- or microscopic well-defined lesions of the oral cavity that would distinguish gastric from colon cancer patients.

\section{References}

1. Knychalska-Karwan Z. Zmiany chorobowe błony śluzowej jamy ustnej u 4752 chorych leczonych w Katedrze i Zakładzie Stomatologii Zachowawczej CM UJ w Krakowie w latach 1961-1998. Mag Stom. 2004;2:10-14.

2. Szponar E, Ślebioda Z, Mania-Końsko A. Występowanie zmian na błonie śluzowej jamy ustnej w przewlekłych chorobach jelit. Dental Forum 2. 2007;XXXV:61-68.

3. Brunotto M, Zárate AM, CismondiA, Fernández M del C, Noherde Halac RI. Valuation of exfoliative cytology as prediction factor in oral mucosa lesions. Med Oral Patol Cir Bucal. 2005;10,Suppl 2:92-102.

4. Epstein JB, Zhang L, Rosin M. Advances in the diagnosis of Oral Premalignant and Malignant Lesions. J Can Dent Assoc. 2002;68,107:617-621.

5. Knychalska-Karwan Z. Obrazy mikroskopowe wymazów nabłonkowych jamy ustnej. Por Stom. 2003;12:19-21.

6. Nayar AK, Sundharam BS. Cytomorphometric analysis of exfoliated normal buccal mucosa cells. Indian J Dent Res. 2003;14:87-93.

7. Woś A, Trzaska E, Żyła P, Zagajewska A, Androsz O. Ocena częstotliwości występowania zmian na języku u osób w wieku podeszłym w zależności od płci, chorób współistniejących i użytkowanych uzupełnień protetycznych. Nowa Stom. 2006;3:128-132.

8. Remmerbach TW, Weidenbach H, Hemprich A. DNA-image-cytometry: diagnostic aid in brush oral cancer. Int Poster J Dent Oral Med. 2001;3:Poster 86.

9. Tamiolakis D, Thomaidis V, Tsamis J, Lambropoulou M, Venizelos J, Papadopoulos N. Qualification of abrasive cytology in the diagnosis of maxillofacial skin and mucosal disorders. Acta Dermatoven APA. 2003;12:68-71.

10. Wieczorek M. Histopatologia ogólna i podstawy cytodiagnostyki. Śląska Akademia Medyczna, Katowice 2006, Wydanie V.

11. Sonis ST, Fey EG. Oral complications of cancer therapy. Oncology. 2002;16:680-695.

12. Pérez-Sayánsm M, Somoza-Martín JM, Barros-Angueira F et al. Exfoliative cytology for diagnosing oral cancer. Biotech Histochem. 2010;85:177-187.

13. Kuklinsky RF. Dental menagement of cancer patients. Chemotherapy consideration. Oncol. 2000;15:29-30.

14. Fukushima H, Fukushima M, Mizokami M, Tanaka T, Ueda H. Case Report of an Advanced Gastric Cancer Associated 
with Diffused Protruded Lesions at the Angles of the Mouth, Oral Cavity and Esophagus. Kurume Med J. 1991;38:123-127.

15. Wijn MA, Keller JJ, Giardiello FM, Brand HS. Oral and maxillofacial manifestations of familial adenomatous polyposis. Oral Diseases. 2007;13:360-365.

16. Knychalska-Karwan Z, Kościelniak D, Franaszek E, Buczko M. Obraz kliniczny i cytologiczny zmian w jamie ustnej w marskości wątroby. Stom Klin. 1994;XV:79-84.

17. Knychalska-Karwan Z, Gackowska M, Franaszek E, Buczko M. Wrzodziejące zapalenie jelit a zmiany w jamie ustnej w świetle badań klinicznych i cytologicznych. Stom Klin. 1994;XV:63-72.
18. Malins TJ, Wilson A, Ward-Booth RP. Recurrent buccal space abscesses: complication of Crohn's disease. Oral Surg Oral Med Oral Pathol. 1991;72:19-21.

19. Baumgart DC, Carding SR. Inflammatory bowel disease: cause and immunobiology. Lancet. 2007;369:1627-1640.

20. Kurman RJ, Malkasian GD, Sedlis A, Solomon D. From Papanikolaou to Bethesda: the rationale for a new cervical cytologic classification. Obst and Gyn. 1991;77:779-782.

21. Queiroz JB, Lima CF, Burim RA, Brandao AA, Cabral LA, Almeida JD. Exfoliative cytology of the oral mucosa: comparison of two collection methods. Gen Dent. 2010;58:196-199.

22. Davey DD. Cervical Cytology Classification and the Bethesda System. Cancer J. 2003;9:327-334.

Submitted: 6 December, 2011 Accepted after reviews: 27 April, 2012 